\title{
Kintamani Bali Arabica Coffee Marketing Strategy Through the Supply Chain and Marketing Mix
}

\author{
I Gusti Bagus Udayana ${ }^{1 *}$, Anak Agung Ngurah Mayun Wirajaya ${ }^{2}$ \\ Universitas Warmadewa, Denpasar-Bali, Indoensia \\ $\left\{\underline{\text { bagusudayana64@gmail.com }}{ }^{1}\right\}$
}

\begin{abstract}
Arabica coffee in Bali is known to have a different taste from coffee in other regions. Currently, the increasing demand for coffee is starting to develop, not only in the form of coffee beans but also for coffee processed products. The coffee agro-industry generally processes coffee beans into ground coffee. The main obstacles to its development are limited market and low added value. Therefore, researchers are interested in researching the Arabica coffee agro-industry in Kintamani Bali sub-district to find a development strategy for the Bali Arabica coffee agro-industry that uses optimal supply chains and high added value. The final objective of this research is to obtain a marketing strategy for Arabica coffee with optimal supply chain and high added value. This goal is achieved in three stages (years) including 1. formulating a supply chain optimization model for the Arabica coffee agro-industry in Bali; 2. a strategy to increase the added value of the Kintamani Bali Arabica coffee agro-industry; and 3. the strategy of the Kintamani Bali Arabica coffee agro-industry marketing mix. The research unit is the Kintamani Arabica coffee farmer group that processes Arabica coffee. The research location was determined intentionally in the coffee centre area as well as having a coffee agro-industry in Bali. The location selection was purposive in Kintamani District, Bangli Regency. The research methods used in this research include descriptive, analytic and comparative methods. Data analysis methods include Marketing analysis, Supply Chain Management and Hierarchy Process Analysis (AHP) to determine the right strategy to optimize the supply chain. In addition to collecting primary data, Focus Group Discussion (FGD) was also conducted.
\end{abstract}

Keywords: Arabica coffee agroindustry; Supply Chain; Value Added

\section{Introduction}

Since 1984, Indonesia has been included as the third world coffee producer and exporter after Brazil and Colombia. [1]. Coffee has a long history and has an important role in Indonesia's economic growth. Indonesia is blessed with a geographic location that is very suitable for coffee plants. Indonesia's position is ideal for a microclimate for coffee growth and production [2]. At first coffee in Indonesia was under the Dutch government. Coffee was introduced to Indonesia through Sri Lanka (Ceylon). Initially, the Dutch government planted coffee in the areas around Batavia (Jakarta), Sukabumi and Bogor. Coffee is also grown in East Java, Central Java, West Java, Sumatra and Sulawesi. In the early 20th century, coffee plantations in Indonesia were attacked by pests, which almost destroyed the entire coffee plant. At that time coffee was also planted in Timor and Flores. The two islands at that time were under Portuguese rule. The type of coffee grown there is also arabica coffee [3] 
Economically important coffee species are Coffea Arabica (Arabica coffee) which is more than $70 \%$ of the world's product and Coffea canephora (robusta coffee). Two other species grown on a smaller scale are Coffea lierica (coffee liberica) and Coffea dewevrei (coffee excels). In the trading world, there are several groups of coffee known, but only Arabica, Robusta and Liberica coffee are cultivated. Arabica coffee has many varieties, depending on the country, climate, and the land where the coffee is grown. This coffee originating from Brazil and Ethiopia controls 70 per cent of the world coffee market. Local coffees such as Toraja, Mandailing, Kintamani and foreign coffees, such as Colombia and Brasilia, are several variants of Arabica coffee. This coffee has a fragrant aroma, similar to a mixture of flowers and fruit. His life is in a cool and cold area [4]

The Kintamani Bali area is a strategic area for coffee plantations because it is a highland area that has a cool climate following the conditions for the development of coffee plants. In this area, apart from the Arabica coffee centre, agro-industries are currently starting to grow, which process coffee beans into ground coffee. The reality is that the coffee agro-industry has not developed rapidly, its market reach is still limited, so researchers are interested in finding a strategy for developing the coffee agro-industry. Agro-industrial development focuses on optimizing the supply chain of the upstream and downstream agro-industry as well as efforts to increase the added value of Arabica coffee processed products.

\section{Method}

\subsection{Place and time of research}

The Phase I research was an experimental survey and data mining in the field in the Kintamani District area in particular and an FGD which took place from April to September 2020. Phase II was the process of a field survey to the coffee industry and an expert survey, which took place in April 2021. SIn detail, the stages of the research process are presented in Figure 1. 


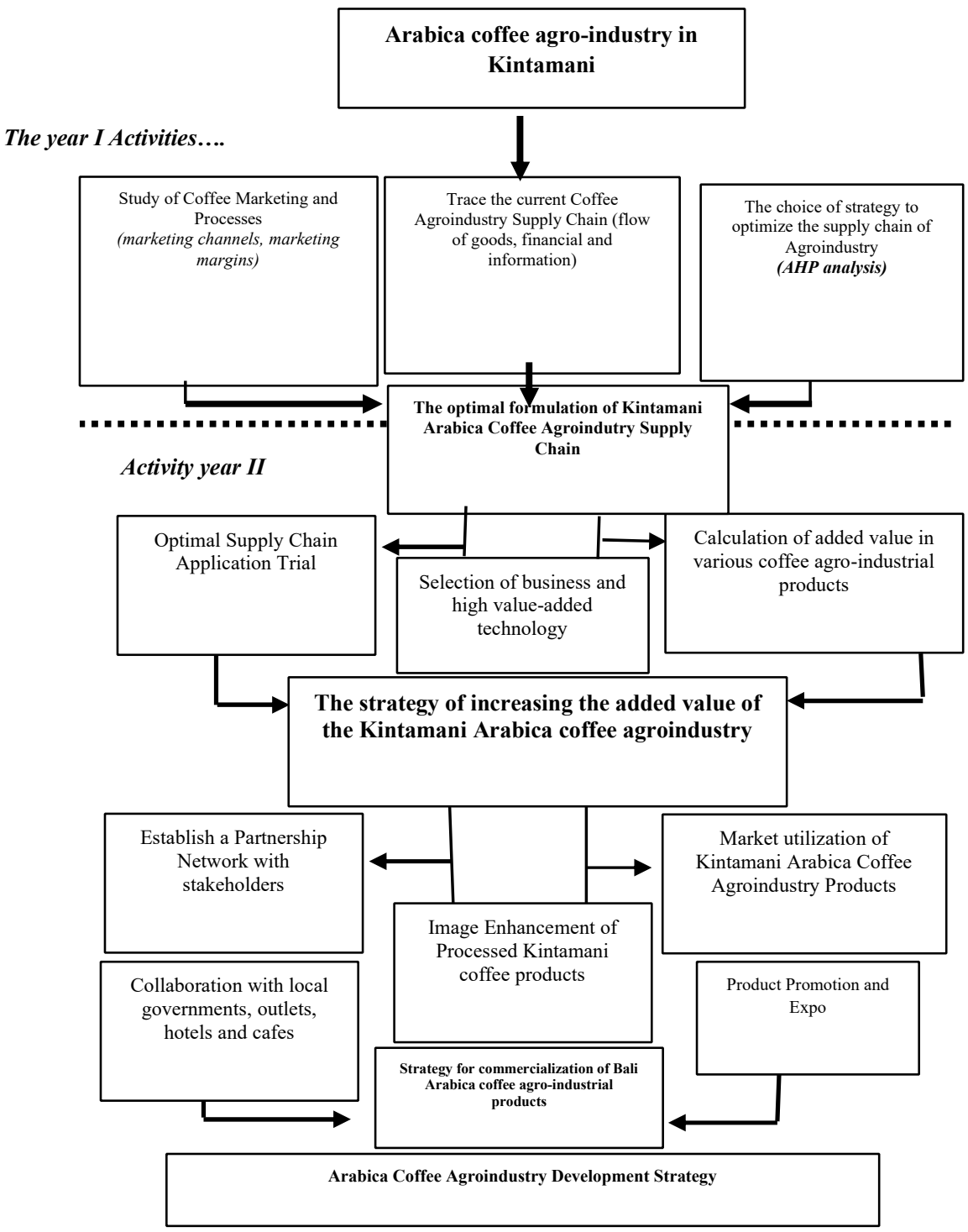

Figure 1. Research Process Flowchart

\subsection{Withdrawal Method Example}

The research unit is farmers who cultivate Arabica coffee and coffee agro-industry. The sampling method used was simple random sampling with a total of 30 farmers in each village. Next, the Snowball Sampling method is used for the marketing process, to trace the marketing agencies involved. The agro-industry that will become the focal firm in the supply chain study was chosen intentionally or purposively, namely the Arabica coffee agroindustry in Kintamani sub-district.

\subsection{Marketing Analysis}


To explain the marketing channel of Arabica coffee farmers in Kintamani District, Bangli Regency, Bali Province, using descriptive analysis method, which is to systematically describe the facts in the field. Marketing channels can be simple and can be very complex. The marketing study was continued on the analysis of marketing margins and distribution of margins in each marketing channel for Arabica coffee. The marketing margin formula is as follows:

$>$ Marketing Margin Analysis

$$
\mathrm{Mp}=\text { Pr - Pf. [5] }
$$

The calculation of profit share, the cost of the marketing agency for Arabica coffee market players in the k-i Kintamani is : [6]

$$
\begin{aligned}
& \mathrm{Ski}=\frac{\mathrm{Ki}}{\mathrm{Pr}} \times 100 \% \\
& \mathrm{Ki}=\mathrm{Pji}-\mathrm{Pbi}-\sum \mathrm{bij} \\
& \mathrm{Sbi}=\frac{\mathrm{bi}}{\mathrm{Pr}} \times 100 \% \\
& \mathrm{Sbi}=\frac{\mathrm{bi}}{\mathrm{MP}} \times 100 \%
\end{aligned}
$$

\subsection{Supply Chain Analysis}

To analyze the second problem, namely the supply chain management system (SCM) which includes product flow, service flow, financial flow and information flow of the Arabica coffee agro-industry in Kintamani District using descriptive analysis methods. The analysis was carried out by tracing the supply chain on the various elements involved [7]

\subsection{Process Hierarchy Analysis (AHP)}

AHP is a method to help arrange a priority from various options using several criteria (multi-criteria) [8]

\subsection{Value-Added Analysis}

To calculate the added value (Value Added) in the Arabica coffee agro-industry. The amount of added value is obtained from reducing the cost of raw materials and other inputs to the value of the product produced, excluding labour

Based on this understanding, the following formula can be formulated:

Information:

$$
V A=V P-I C
$$

VA: Value Added or Added Value on processed products ( $\mathrm{Rp} / \mathrm{Kg}$ of raw materials).

VP: Value Product or Production Value, namely the sale of products ( $\mathrm{Rp} / \mathrm{Kg}$ of raw materials). 
IC: Intermediate Cost namely costs that support the production process in addition to costs labour ( $\mathrm{Rp} / \mathrm{Kg}$ of raw materials).

Decision-Making Criteria:

a. $\mathrm{VA}>0$, added value in coffee processing can provide positive value

b. VA $\leq 0$, added value in coffee processing can provide a negative value

The calculation of added value is carried out for all processing alternatives starting from bean coffee (ose coffee) in the upstream agro-industry to processing (main, derivative and byproducts) in the downstream agro-industry.

\section{Results and Discussion}

The results of the questionnaire from the treatment of roles between actors involved in the preparation of a competitive Kintamani arabica coffee agroindustry supply chain strategy found that the actors who played an important role in the marketing strategy of Kintamani Arabica coffee were stakeholders with a value of 0.539 , the second position was the industry and trade service with a value of 0.244 , the third position. is the plantation agency 0.123 and the last one is the university 0.094 . This data is shown in Table 1.

Table 1. Roles of Involved Actors

\begin{tabular}{lll}
\hline No & \multicolumn{1}{c}{ Actor } & Priority Value \\
\hline 1 & Stakeholders & 0.539 \\
2 & Department of Industry \& Trade & 0.244 \\
3 & Plantation Service & 0.123 \\
4 & College & 0.094 \\
\hline
\end{tabular}

The results of the questionnaire on the treatment of the level of potential between products in the Kintamani Arabica coffee agroindustry in determining superior products, it was found that herbal coffee was the selected product that was prioritized to be processed products, the priority value was obtained with a value of 0.160 . The second priority product is ground coffee with a priority value of 0.127 , and the third priority product is ready-to-drink coffee with a priority value of 0.125 . (Table. 2 )

The results of the questionnaire on the treatment of strategies in the preparation of supply chain strategies for the Kintamani Arabica coffee agro-industry competing in the supply chain strategy of the Kintamani Arabica coffee agro-industry resulted in maintaining relationships with suppliers as a priority strategy with a value of 0.147 , Preparing SOPs, the problemsolving method is the second priority strategy with a priority value of 0.124 . , and the formation of a problem-solving team is the third priority strategy with a priority value of 0.076. (Table 3.) 
Table 2. Level of Potential between Products at Kintamani Arabica Coffee Agroindustry

\begin{tabular}{llc}
\hline No & \multicolumn{1}{c}{ Product } & Priority Value \\
\hline 1 & Herbal Coffee & 0,160 \\
2 & Coffee powder & 0,127 \\
3 & Coffee Ready to Drink & 0,125 \\
4 & Design Coffee & 0,115 \\
5 & Coffee Mix & 0,115 \\
6 & Strong Coffee & 0,110 \\
7 & Taste Coffee, Food, Candy & 0,105 \\
8 & Coffeine & 0,095 \\
9 & BIN Coffee & 0,048 \\
\hline
\end{tabular}

Coffee is one of the plantation commodities which has a high economic value among other plantation crops (Yusdiali, 2008). Coffee consists of many types, including those that are often found, namely Arabica coffee (Coffea arabica) and robusta coffee (Coffea canephora). Arabica coffee has superior characteristics and taste compared to robusta coffee [9].

\subsection{The roles of actors involved in the preparation of a competitive Kintamani Arabica coffee agroindustry supply chain strategy}

The results of the questionnaire found that the actors who played an important role in the marketing strategy of Kintamani Arabica coffee were stakeholders with a value of 0.539 , the second position was the industry and trade service with a value of 0.244 , the third position was the plantation service 0.13 and the last one was the university 0.094 . Stakeholders are actors in the company, which consists of shareholders, management, employees, suppliers. The roles of parties who have primary interests or stakeholders, namely:

1. The owner (owner) or Shareholders

Initially, a business starts from the idea of someone or more about a good or service and they spend money (capital) to finance the business, because they have the belief that in the future they will get a reward (profit) and they organize, manage and bear all risks. business.

2. Employee (employee)

Employees are people who are appointed and assigned to carry out company activities. Company performance is highly dependent on the performance of all employees, both individually and as a group.

3. Management

Management is a manager who is under the control of the owner, only with sufficient capacity can a manager appear autonomously in managing the company.

4. Supplier (supplier)

Suppliers are partners of companies that are ready to meet the availability of raw materials, therefore the company's performance also depends partly on the supplier's ability to deliver raw materials on time. For example, suppliers of interests, if the goods and services they supply are relatively step-by-step and difficult to obtain substitute goods/services, the relative strength of the organization to stakeholders is not always weak

stakeholder within the company is various parties that have a direct or indirect relationship with the success or failure of the company's processes. When talking about stakeholders, every company must be able to create its company complete with all the systems, tools and attributes that can meet the expectations of the community in general and the parties with an interest in the company. In other words, companies cannot go "selfish" alone. Companies must be able to 
establish communication, relationships and networks with various parties to support the success of the expected goals and ideals of the company. In terms of function, the existence of stakeholders is almost the same as that of a leader. Thus, stakeholders must also have a high sense of responsibility for realizing the goals and ideals expected in a company. In its development, the company requires specific and measurable management, including management of its reputation. Reputation for an organization/company is vital because the life and death of a company depend on the company's ability to manage its good reputation.

In agribusiness activities, there is a simple definition of corporate reputation, which is an assessment that is carried out continuously by stakeholders on the attributes, symbols, ownership associated with the organization/company. Each organization/company will evaluate the organization/company assessment from the point of view of different stakeholders. So that the organization/company has a different reputation among each stakeholder group, the company's reputation is considered very important because stakeholders are more concerned with this concept. Stakeholders realize that the company's image and brand influence them. The reputation of the organization in the minds of stakeholders plays an important role in the shape of their behaviour and the decision-making processes related to the organization. As a result, many organizations consider the importance of achieving high reputation quality among their stakeholders. The role of corporate communication in an organization that the company should play an important role in managing the company's reputation.

Organizational reputation is the responsibility of every member of the organization. So that top management and communication policy must be in line with the reputation. So that the reputation aspect becomes value-driven and is placed as the main agenda. The importance of reputation makes companies that are aware of this race to convince stakeholders of their reputation. Stakeholder assessment is not sufficient to come from assumptions alone, but more thoroughly. Stakeholders will assess the reputation of the information they get about the company's activities from various sources, including themselves, the media, or other parties. So, it is not surprising that companies affected by the crisis are willing to spend large sums of money to improve their identity so that their fallen reputation is not allowed to drag on, as well as a reputation that must be built and started from the top management level first so that all stakeholders see that the goodwill and seriousness of the organization represented in top management is something that deserves to be trusted. Next, reputation is also based on performance, not based on communication alone. This means that with good performance, a reputation will indirectly be formed in communicating with internal and external stakeholders so that it is not based on imagery and pseudo-representation.

\subsection{The potential level between products in the Kintamani Arabica coffee agroindustry in determining superior products}

Coffee is widely used as a refreshment drink because it has a distinctive taste, so it is favoured by various levels of society around the world. Coffee drinks are made from steeping processed coffee products that are often found, for example, ground coffee (Azizah et al., 2019). The results of the questionnaire found that herbal coffee is the selected product that is prioritized to be processed products, the priority value is obtained with a value of 0.160 . The second priority product is ground coffee with a priority value of 0.127 , and the third priority product is ready-to-drink coffee with a priority value of 0.125 .

Herbal coffee is a general term for defining coffee products that have been enriched with herbs or spices such as ginger, peg Bumi (Eurycoma longifolia), Panax (from the genus Panax L.), Black Seed (black cumin / black bean / Nigella sativa) and herbs or spices. other. The 
enrichment of ingredients in coffee is not only to increase the acceptance of coffee itself but more importantly also to increase its nutritional value [10] [11].

Table 3. Kintamani Arabica Coffee Agroindustry Supply Chain Strateg

\begin{tabular}{llc}
\hline No & \multicolumn{1}{c}{ Strategy } & $\begin{array}{c}\text { Priority } \\
\text { Value }\end{array}$ \\
\hline 1 & Maintain relationships with suppliers & 0.147 \\
2 & Prepare SOPs, problem-solving methods & 0.124 \\
3 & Problem-solving team & 0.076 \\
4 & Making Customer service respond to complaints and input & 0.068 \\
5 & Performance Measurement & 0.064 \\
6 & Performance evaluation & 0.058 \\
7 & Periodic Marketing Event & 0.056 \\
8 & Improvement through HR training and technology development & 0.056 \\
9 & Create an attachment (membership) & 0.048 \\
10 & Make an alternative raw material substitute & 0.047 \\
11 & Evaluation and adaptation of products to consumer needs & \\
& periodically & 0.047 \\
12 & Making Customer service is a service and offering & 0.046 \\
13 & Sales through retailer agents & 0.040 \\
14 & Sales via e-commerce & 0.038 \\
15 & Making SOP for procurement of goods & 0.031 \\
16 & Make your supply of raw material sources & 0.027 \\
17 & Take control of the production and warehousing systems & 0.018 \\
18 & Create production scheduling & 0.010 \\
\hline
\end{tabular}

Herbal coffee is also known as nutrient-fortified coffee due to reports that the combination of caffeine and herbal supplements has a more effective effect on increasing the metabolic rate than consuming caffeine alone [12]

\subsection{Strategies in developing a competitive Kintamani arabica coffee agroindustry supply chain strategy}

The results of the Kintamani Arabica coffee agroindustry supply chain strategy questionnaire are that maintaining relationships with suppliers is a priority strategy with a value of 0.147 , preparing SOPs, the problem-solving method is the second priority strategy with a priority value of 0.124 , and the formation of a problem-solving team is the third priority strategy with a priority value of 0.076. (Table 3). [13] [14]

Understanding the relational construct cannot be separated from the discussion regarding the concept of relationship marketing, in this case, a company (focal firm) to be able to excel in competition must have good relationships with four main parties: supplier partnerships (including good suppliers and services suppliers), lateral suppliers (competitors, nonprofit organizations, and government), buyer partnerships (intermediate customer ultimate customers), and internal partnerships (business units, employees and functional departments) [15] [16]. 


\section{Conclusion}

The conclusion of this study is to carry out several strategies, namely: 1). Maintain relationships with suppliers with a value of 0.147. 2) Preparing SOP, the problem-solving method with a value of $0.124,3$ ) Problem-solving team with a value of $0.076,4)$ Making customer service respond to complaints and input with a value of $0.068,5$ ) Measurement of performance with a value of $0.064,6$ ) Performance evaluation with a value of $0.058,7$ ) Marketing events periodically with a value of $0.056,8)$ Improvement through human resource training and technology development with a value of $0.056,9)$ Creating an attachment (membership) with a value of $0.048,10$.) Making alternative raw materials for substitutes with a value of $0.047,11$ ) Evaluation and adaptation of products to consumer needs periodically with a value of $0.047,12$ ) Making Customer service services and offers with a value of 0.046 ,

\section{Acknowledgments}

Thank you to all those who have helped with this research activity. To the head of the Unwar Chancellor and the Chair of Lemlit and his staff for the assistance of institutional research grants that we have used for this research activity. Thank you to our partner, Mr Suedi, who has been willing to be a partner in our research and we don't forget to say to the village head and his officials who helped a lot in this research event.

\section{References}

[1] G. B.Udayana,. "Model Development Industrial Cluster Coffee Arabica in The District Bangli, Province of Bali," International Journal Ijaseid. vol. 15. 2015

[2] I. G. B. Udayana, "Arabica Coffee Marketing Strategies With Information Technology In Kintamani District Bangli," International Journal of College \& University (IJCU), volume 33, 2017

[3] Karya farmer, 2010.

[4] P. Rahardjo, "Guide for the Cultivation and Processing of Arabica and Robusta Coffee,"Jakarta: Self-help spreader, 2012

[5] A, Sudiyono, "Agricultural Marketing," Malang: University of Muhammadiyah Malang Press, 2002

[6] A. Rahim, and Hastuti, "Introduction, Theory, and the Case of Agricultural Economics.”Jakarta:Self-Help Spreader, 2007

[7] J. Heizer and B. Render, "Operations Management Sustainability and Supply Chain Management 11th edition," Pearson Education International, 2014

[8] Marimin, “Application of decision-making techniques in supply chain management," IPB. Press, 2011

[9] S. Najiyati, and Danarti, "Coffee, Cultivation and Off-Harvest Handling," Mould XI. Jakarta: Self-help spreader, 2001

[10] C. Dullo, "Coral growth and reef growth: a brief review," Facies volume, pp. 33-48, 2005 
[11] A. T. Roberts, L. D. J.Levitan, C. C. Parker. And F. L. Greenway, "The effect of a herbal supplement containing black tea and caffeine on metabolic parameters in Humans," Alternative Medicine Review, volume 10, pp. 321-325, 2005

[12] J. R. Hoffman, J. Kang, N. A. Ratamess, P. F. Jennings, G. Mangine, and A. D. Faigenbaum, "The thermogenic effect from nutritionally enriched coffee consumption," Journal of the International Society of Sports Nutrition, volume 3, pp. $35-41,2006$

[13] Morgan, M. Robert, D. Shelby and Hunt, "The Commitment - Trust Theory of Relationship Marketing," Journal of Marketing, volume 58, nomor 3, pp. 20-38, 1994

[14] Marimin, "Technical Applications of Decision Making in Supply Chain Management". IPB Press: Bogor, 2010

[15] S. Gumbiran, "Agribusiness Management". Ghalia Indonesia, 2001

[16] Soekartawi, "Introduction to Agroindustry," Raja Grafindo Persada: Jakarta, 2000 